\title{
G.K. CHESTERTON AND THE QUEST FOR HEIDEGGERIAN AUTHENTICITY
}

CLARE CHIODINI

T

The public careers of G. K. Chesterton, novelist and Catholic convert, and Martin Heidegger, philosopher and lapsed Catholic, overlapped for roughly twenty-five years from the beginning of the second decade of the 20th century. ${ }^{1}$ In this paper, I will seek to foster a dialogue between these two authors by analyzing one of each's most famous works: Heidegger's Being and Time ${ }^{2}$ and Chesterton's The Ball and the Cross. After describing Heidegger's thought, we will show that Chesterton, like his German counterpart, understood the difference between an authentic and a fallen existence (what Heidegger calls 'Dasein'3 ${ }^{3}$ ), by demonstrating how this understanding is exhibited in his novel. However, despite their many similarities, the two works differ in a crucial way. Highlighting this divergence, Iwill conclude by arguing that Heidegger's explanation of guilt and resoluteness is incomplete without

1 Chesterton was born in 1874, fifteen years before Heidegger, and died in 1936, forty years before Heidegger's death.

2 In Being and Time, Heidegger contends that philosophy has ceased to explore the question of Being's meaning, considering it to be a universal or self-evident concept that resists definition. Heidegger therefore sets out to formulate a conception of Being itself. However, the Being he seeks to define is the Being of particular entities, which may be designated as beings with a lower case ' $b$ '. In order to understand Being in itself, Heidegger decides it is first necessary to gain access to a particular entity, or being, as it is in its Being. The entity he prioritizes towards this end is Dasein.

Heidegger, Martin, Being and Time (New York: Harper \& Row, 1962), pp. 6-8.

3 In Heideggerian language, Dasein denotes the particular being whose Being matters to it. Dasein must be distinguished from other objects in the world because it "relates to its existence always as its own... it exists in the first-person as a 'who' not a 'what'." Although 'Dasein,' as a German term, is held as untranslatable, it may be roughly understood as a combination of the verb 'to be' and the adverb for 'place'. Therefore, Dasein indicates 'a being which is here'. For Heidegger, "being-here is not reducible to merely occupying a space. To be-here is to experience a world opening up."

Dahlstrom, Daniel O., The Heidegger Dictionary (New York: Bloomsbury Publishing Plc, 2013), p. 35. 
something exemplified by the characters in Chesterton's novel, i.e., without a reason for choosing to choose.

\section{PART I}

In section 60 of Being and Time, Heidegger writes that 'resoluteness' is "the reticent self-projection upon one's ownmost Being-guilty, in which one is ready for anxiety." This statement culminates many chapters worth of explanation, which I shall attempt to summarize and explore below.

Resoluteness is essentially the projection of one's possibilities in light of one's existential'5 state of guilt. By 'guilt,' Heidegger does not mean to suggest a moralistic, dooming sensation of having done wrong. While the philosopher does not deny a relationship between morality and guilt, he understands the latter as being a condition for the former: one can be morally good or evil because one is primordially Being-guilty. ${ }^{6}$ This existential sense of Being-guilty Heidegger defines as "Beingthe-basis of a nullity." This meaning is two-pronged: in the first place, there is nothing Dasein can point to as the basis of its existence - of its factical projection of potentiality-for-being. In the second place, however, Dasein finds itself responsible, despite this lack of basis, for choosing one possibility over another. It is responsible for its freedom to project some possibilities while rejecting others. This freedom is not a cold fact, but rather is a burden to Dasein. The authentic seizure of certain possibilities is a responsibility it must undertake for itself. The implications of this freedom bear heavily on Dasein's relation to its own being. As I shall explain below, Dasein's conscience identifies its guilt by recalling itself from its state of being lost in the 'they"' (the crowd) ${ }^{8}$.

4 Heidegger, Being and Time, p. 297.

5 Existentials are ontological facts which describe the mode of Dasein's Being; they are the, "characters that make it up existentially. Since Dasein is its disclosedness, existentials at once constitute-and-disclose existence as Dasein's Being." Being-in, Being-Alongside, and "they" are examples of existentials. Conscience, death and guilt are examples of existential phenomena.

The term "existential" must be differentiated from another, similar term - "existentiel". An existentiel understanding of Dasein refers to that being as it is encountered and described in our more immediate, daily experience. Heidegger seeks to ground his study of existential Dasein in its existentiel understanding. Dahlstrom, The Heidegger Dictionary, p. 70.

6 Being-guilty simply implies that, "Dasein as such is guilty," given that guilt is an existential which indicates Dasein's necessary ability to choose between potentialities. Being-guilty means that Dasein has assumed the responsibility of that choice.

Ibid., p. 284.

7 Ibid.

8 'They' indicates the general crowd, the public opinion which dominates society. Heidegger makes clear that the 'they' is not anything definite and cannot be viewed as the conglomeration of many individuals. Rather the 'they' is constituted by the indefinite others into which every Dasein sinks by participating in a public culture: transportation, information, etc. Its concern is to make everything average. The 'they' is an existential, because it is the mode in which Dasein exists for the most part; it is Dasein's everyday "Being-one's-Self”. However, it is an inauthentic-self, because as 'they' Dasein does not act resolutely, but rather ignores its responsibility to guilt and allows others to make its decisions for it.

Ibid., pp. 127, 271. 
Heidegger describes conscience as a call that summons Dasein from its fallenness ${ }^{9}$ to its ownmost potentiality-for-Being ${ }^{10}$. It is a call that works as a countermeasure to Dasein's "listening away." 11 In its everyday Being, Dasein is absorbed in the world of the 'they' (the worlds of anonymous social groupings or crowds) and Heidegger calls this mindless absorption a state of "falling." In this state, Dasein finds itself tempted to surrender its authentic potentiality-for-being ${ }^{12}$ and submit itself to the interpretation and nearly subliminal control of the 'they' as expressed in Idle Talk, ${ }^{13}$ Curiosity, and Ambiguity. Concretely then, in its everyday being Dasein listens to gossip and reads magazines without ever verifying whether what is said-in-the-talk has any meaningful relationship to the true being of the entity discussed. It abandons itself to a constant interest in the superficial, restlessly seeking "continual novelty and changing encounters," ${ }^{14}$ all the while refusing to bring the encountered thing close and understand it. It is always talking and "surmising" ${ }^{15}$ about future events and possible courses of action, yet never acts itself. Living under the proscription of the 'they', Dasein is tranquillized into complacency. It loses the desire to make life more challenging and thus avoids facing its ownmost possibility, effectively alienating itself. It looks away from the significance and potentiality of its Being, and focuses entirely on things theoretically present-at-hand or practically ready-to-

9 Fallenness is an existential: a particular mode of Dasein's Being which describes Dasein's existential state of "Being-in" in its everydayness. Being-in has three basic existential constituents: attunement(or mood), understanding, and discourse.

Moods evidence the emotional life of Dasein. In moods, Dasein discloses to itself that it has been thrown into the world. Although "thrown" is a complex concept in Heidegger, we can understand it as the fact that the individual Dasein exists within a particular place at a particular time with particular people; what Heidegger describes as Dasein's facticity. Dasein's mood indicates to Dasein that it has been thrown into the world in a certain way. By revealing itself as thrown, Dasein's mood allows for what is encountered within-the-world to matter to Dasein.

Understanding as an existential has to do with understanding the "for-the-sake-of-which" (143) of Dasein. Heidegger emphasizes that Dasein does not exist as a thing before its possibilities, but rather projects possibilities and understands itself through them. In this sense Dasein is its possibility existentially. Possibility as an existential is not a logical or present-at-hand possibility, but "the most primordial and ultimately positive ontological determinacy of Dasein" (143). In understanding, Dasein becomes apparent to itself in terms of the referential totality of its potentialities for being. It is essentially "thrown possibility" (143). This potentiality-for-being is inextricably tied to guilt: it does not indicate a conglomeration of hypothetical possibilities, but, instead, indicates the fact that Dasein is in every case this potentiality-for-being rather than that one.

Discourse refers to the fact that Dasein's projection of its possibilities brings it into relation with others as Being-with. Through discourse Dasein expresses itself in terms of its state-of-mind. In this expression, the understanding of the world (of Dasein as Being-with Others and as Being-in-the-world) is disclosed to Others.

Fallenness is Being-in-the-World as it "maintains itself in the everyday Being of the They" (167). Fallenness indicates Dasein's basic tendency to conform. Dasein is thrown into the public sphere and thus, for the most part, pays attention not to the Being of itself, but of the 'they'. Additionally, the 'they' hampers Dasein's capacity to understand itself as potentiality-for-Being because it appropriates Dasein's possibilities, depriving Dasein of its responsibility to decide for itself.

Ibid., pp. 131-167.

10 Ibid., p. 271

11 Ibid.

12 Ibid., p. 167.

13 Idle Talk can be understood as the existential of discourse as a character of fallen Dasein; it is discourse submitted to the control of the 'they'. Having lost its relationship of Being to the entity discussed, discourse becomes mere gossiping.

Ibid., p. 168.

14 Ibid., p. 172

15 Ibid., p. 174. 
hand. ${ }^{16}$ Indeed, it often reduces itself to such entities, never bothering to look past a theoretical dissection of its inner workings to the uncomfortable facticity of its potentiality-for-being. Nevertheless, it is this very discomfort which calls Dasein back from such groundlessness.

The call of conscience breaks through public, worldly interpretations to the Dasein that has abandoned itself to them. With an 'alien' voice, this call recalls Dasein to its ownmost potentiality for being, a being accompanied by a feeling of the greatest uncanniness. ${ }^{17}$ To understand what we mean by this latter term we must first offer a brief description of anxiety. Fallen Dasein is Dasein which, existentially, has not understood itself in terms of its own possibilities. It turns away from a disclosure of itself as, "authentic potentiality-for-Being-its-Self"18 and allows for absorption in the concerns of the 'they'. Dasein's falling, therefore, can be understood as a fleeing away from something threatening. Heidegger clarifies that he is not speaking of fleeing as grounded in the mood of fear and evoked in the face of a definite threat (something ready-to-hand or present-at-hand). Instead, in falling, Dasein flees in the face of itself; in the face of Being-in-the-world. This fleeing is grounded in the basic state-of-mind, or mood, which Heidegger calls anxiety, and which reveals to Dasein the threat imposed by Being-in-the-world. As he writes, "that in the face of which one has anxiety is completely indefinite...[i]t tells us that entities within-the-world are not relevant... it is characterized by the fact that what threatens is nowhere." ${ }^{19}$ In anxiety, the "nothing and nowhere" of the world become manifest; the entities, or beings, become utterly insignificant. However, this insignificance does not mean the world holds no meaning for Dasein. Rather, "what oppresses us...is not the summation of everything present-at-hand; it is rather the possibility of the ready-tohand in general; that is to say, it is the world itself." ${ }^{20}$ Being is anxious in the face of no thing - no specific entity within-the-world. Instead, anxiety arises when we face the full horizon of our possibility.

16 An object that is present-at-hand is an object that Dasein relates to within the world as a mere fact. Whether it is the fact of a physical thing or a theoretical concept, it is something that is present within the world and may be theorized about, but is not used. It differs from an object that is ready to hand and that is related to as something useful and to be implemented or handled. An object ready-to-hand is bound up in a network of references which determine its purpose (traceable finally to the service of Dasein).

Ibid., p. 73-75.

It is important, moreover, to distinguish (as Heidegger does) between presence and being. He maintains that the history of philosophy has largely equated the two, such that presence has taken on a metaphysical meaning. It intimates "present-ness" and "accessibility to someone here and now." Heidegger argues that the Greeks failed to see that they were interpreting being in terms of time and restricting it to the present. Thus, they had failed to arrive at a more primordial form of being in which absence is not to be considered. Heidegger considers "presence" as the event that, "grounds and affords the coming to presence... [it] encompasses the... having been and the future, since all... are in a way present to us - even... because of the ways they are absent."

Dahlstrom, The Heidegger Dictionary, p. 173.

17 Heidegger, Being and Time, p. 277.

18 Ibid., p. 184.

19 Ibid., p. 186

20 Ibid., p. 187. 
Yet Dasein is not only anxious in the face of something, but also about something. This "about", as with "in the face of", is no definite being, but rather is Being-inthe-world itself. ${ }^{21}$ In anxiety, the world and all its entities lose their power to define Dasein, and that being is thrown back upon its own authentic potentiality-for-being; it is individualized as "being-possible." 22 As Heidegger writes, "anxiety makes manifest in Dasein its Being towards its ownmost potentiality-for-Being - that is, its Beingfree for the freedom of choosing itself and taking hold of itself." 23 In other words, anxiety emerges when, in the face of its horizon of possibilities, Dasein recognizes its guilt - its responsibility of choice. This position of being is a vulnerable and uncomfortable one: "in anxiety one feels uncanny... 'uncanniness' also means 'notbeing-at-home'." ${ }^{24}$ Guilt, then, is a burden in this sense: though it may become one, it is not necessarily a grievous weight, but rather the discomfort of one's individual responsibility to choose among possibilities in light of the urgency endowed by one's ownmost possibility. This position of uncanny discomfort is entirely at odds with the obvious tranquility of the 'they', and its comforting assurances of being-at-home. Returning to our initial theme of conscience, it is clear now that Dasein, uncanny in its anxiety, serves as a countermeasure to the falling of Dasein. As Dasein attempts to flee mindlessly into the "they", anxiety grips it and, in this grip, Dasein calls itself back to its responsibility of choice before its ownmost possibility.

It has been said that anxiety brings Dasein before its ownmost potentiality-for-Being, but we have yet to explain what this potential is. Simply, it is death. According to Heidegger, death is not a truncating end or conclusion to Dasein, but rather a fundamentally individual possibility of impossibility. It is the possibility of a point at which Dasein will no longer be free to choose from its grand horizon of possibilities. ${ }^{25}$ Being-towards-death ${ }^{26}$, which Heidegger calls anticipation, is essentially allowing oneself to be open to the threat arising from the throwness of one's being: the threat that one has been thrown into the world to die and that one must choose one's possibilities in the face of this ultimate fact. However, this threat is not negative, for because of it, Dasein is called back to an authentic state-of-being in which its possibilities are freed for their truth. Anxiety, as the state-of-mind which holds open (or stands before) the threat of Dasein's ownmost possibility, drags Dasein back from

21 Ibid.

22 Ibid., p. 188.

23 Ibid.

24 Ibid., p. 189

25 Death is an existential possibility which is present to Dasein in every moment. Death makes itself present (in the sense of presence explained above) in the present as a possibility of Being impending on Dasein. Furthermore, it is Dasein's ownmost possibility. Ownmost as it is used by Heidegger means that which belongs most closely to oneself. Of every possibility Dasein possesses, death is the most personal. No one can die for you, and thus it is the one thing Dasein must inevitably do for itself. The fundamental characteristics of death are: ownmost, not-shared, not-to-be-overtaken, certain, and indeterminate. Due to lack of space to address these aspects individually, they are simply assumed and occasionally referenced in this paper.

26 Being-towards-death indicates that Dasein, in its Being, concerns itself over death as a possibility. It is not brooding over or theorizing about death; rather, it indicates a way of relating to death as each Dasein's ownmost possibility; it is the anticipation of this possibility.

Ibid., p. 260. 
fallenness in the call of conscience. In other words, anxiety brings Dasein into an authentic state of being. ${ }^{27}$ Moreover, death grants Dasein liberty, for by making Dasein's possibilities stand out in the horizon of existence, it frees it. For example, world travel is always a possibility, yet one usually absent from the thoughts of the everyday man. Tell this man that he will soon die, and suddenly the possibility which was always present - but never understood - stands out as a copper relief from its setting. At this point, death's purpose in our grand scheme should be apparent: in Being-towards-death, Dasein becomes capable of living authentically, free to choose from the full range of its possibilities.

We are now ready to rejoin our discussion on the topic of resoluteness. Conscience is the call which summons Dasein away from its fallenness to stand before its potentialityfor-Being. Its voice belongs to the being most alien to fallen Dasein, namely, Dasein "individualized down to itself in uncanniness and [...] thrown into "nothing."." 28 Hearing this voice - or summons - correctly means, "having an understanding of oneself in one's ownmost potentiality-for-being - that is... projecting oneself upon one's ownmost authentic potentiality for becoming guilty." ${ }^{29}$ In other words, conscience calls one to recognize the fact of one's responsibility of choice in light of one's ownmost potentiality for death. Understanding the call is choosing to have a conscience, i.e. wanting to be called to an undertaking of this anxious, burdensome responsibility of choice. In this wanting to have a conscience, Dasein is disclosed, and it is this disclosedness of our possibilities that we call resoluteness. Resoluteness essentially entails the projection of possibilities in relation to guilt. Called in anxiety to an openness before our responsibility of choosing possibilities (in view of death), we project actual possibilities: we choose; we live authentically.

\section{PART II}

I will now argue that G.K Chesterton understood the phenomenon of conscience and fallenness that we have outlined above. In his novel The Ball and the Cross, Chesterton presents characters whose persistence in conflict, and eventual friendship, set them apart from the crowd. Indeed, their entire story centers around the imminent possibility of death, and the way in which their authentic choices and interactions

27 Dasein's existence may be lived authentically or inauthentically because it understands itself as the possibility of being itself or not. Existentially, Dasein is its possibility. Anxiety brings Dasein face to face with its Being-free for its possibilities, the ownmost of which is death. Because Dasein relates to its Being in terms of "its ownmost possibility", "it can lose and find itself" $(38,42)$. This is because Dasein's potential to be authentic or inauthentic corresponds to certain existentiel possibilities. What those particular existentiel possibilities may be differs from person to person and, therefore, it is impossible to state exactly what form an authentic existentiel possibility takes. Nevertheless this much is certain: Dasein's authentic Being necessitates it face its potentiality-for-Being in view of the urgency bestowed by its ownmost possibility (death). The existentiel possibilities which it then chooses will be ones in which Dasein finds itself and acts according to the truth of its Being.

Ibid., pp. 38-42.

28 Ibid., p. 277

29 Ibid., p. 287. 
constitute a marked difference from the 'they'. ${ }^{30}$ To begin this discussion I will offer a summary of the novel.

Evan Maclan, a stolid Catholic hailing from Scotland, arrives in London one afternoon, and after wandering around the large city, eventually finds himself outside the editorial office of The Atheist. Absentmindedly, the young Catholic begins to read a paper pasted to the window, and, therein discovering blasphemy against the Virgin Mary, shatters the glass and challenges the surprised editor within to a duel. The editor's name is James Turnbull, and as fervently as Maclan follows the tenets of his Catholic faith, Turnbull declares the triumph of atheism and the death of God. However, in this initial encounter between the two, one element of their respective creeds becomes starkly apparent: their beliefs are not ideologies which, having been subscribed to, have closed the men off, but, rather, are the reason for an authentic relationship with one another. Indeed, far from being enraged by his damaged property, Turnbull turns, "deadly pale with pleasure" and is happy that "someone was angry with the paper"31 ; he is happy that at last he has an opportunity for authentic dialogue. Joyously accepting MacIan's proposal for a duel, the two make preparations for a fight to the death in defense of their respective creeds.

Yet, the passionate Scotsmen (for that nationality encompasses both) find themselves continually baffled in the attempt to engage. Any two men willing to engage so authentically over the 'trivial' motive of religion must be mad. Hence, their story unfolds as a grand chase across Britain with the police and public on their tails. Each time the men begin to fence, something or someone prevents them, leading to an encounter with a series of unusual, or rather, uncomfortably usual, characters. In the end, Turnbull and MacIan are tricked into an asylum from which there is no escape. After a period of solitary isolation, they emerge to discover that every individual encountered along their way has been made an inmate alongside them. This discovery leads to a concluding confrontation with the master of the asylum, and the end of the novel.

One of the main themes of this book is the way in which the general obviousness of public interpretation obscures the meaning of the Scots' duel. It amounts to a description of what Heidegger would label the "fallenness" of Dasein. The reduction of the believers' meaningful feud is made especially clear after the gentlemen's first attempt at a fight to the death is checked by police interference. Having satisfied readers as to the safe escape of the protagonists, Chesterton launches into an account of journalism and the manner in which newspapers responded to the cataclysmic event of a religious duel:

30 Two aspects are worthy of note regarding our following discussion. The first is that, in examining the resoluteness of the Scotsmen, we are essentially displaying an example of existentiel authenticity. The second is that, because these characters are Chesterton's productions, they reveal primarily the thought of that author, and are thus removed from an observation of people actually existing in the world.

31 Chesterton, G.K, The Ball and the Cross (Sioux Falls: NuVision Publications, LLC, 2008), p. 22. 
"Whatever secret and elvish thing it is that broods over editors and suddenly turns their brains, that thing had seized on the story of the broken glass and the duel in the garden.... Mr. Maclan, one of the combatants, became for some mysterious reason, singly and hugely popular as a comic figure... he was always represented... with red whiskers... Letters under the heading "Where are They" poured into every paper... running them to earth in the Monument, Twopenny Tube, Epping Forest, Westminster Abbey...."32

This description bears fascinating similarities to Heidegger's account of "Idle Talk", a characteristic of Fallenness. In the scribbling of various journals it becomes impossible to verify whether what has been said is, or is not, factically true. Maclan is neither comic nor red-haired, and as the Scotsmen read the newspapers they are seated not in any of the locations announced, but on a hill to the north of London. There is no way, however, for the common newspaper reader to know that. What has been said-in-the-talk, or in this case, written in the articles, has become its own subject, severed from the being of the entities discussed and passed around to a public which accepts the script without question. This fake form of dialogue has closed off and covered up the facticity of Maclan's challenge. Truth has not been challenged as a lie, but dismissed as a joke. The words have garbled the facts, and readers not bothering to confirm have stopped at the garbling.

Chesterton beautifully demonstrates the difference between fallen Dasein attempting to play the part of public conscience and an authentic being's understanding of that call. The first character whom Maclan and Turnbull meet on their journey is described in his chapter title as a "philosopher of love". Coming across the duelists as they join swords, the man recognizes them from what he has read in the papers, and in the manner of multiple thinkers whom he names, attempts to "appeal to [their] higher natures". At one point in his empty overture, the man remarks, "well, we won't quarrel about a word," immediately sparking a vehement reaction from MacIan. "What is the good of words if they aren't important enough to quarrel over? Why do we choose one word more than another if there isn't any difference between them?" ${ }^{33}$ MacIan's reply is a direct refutation of Idle Talk and its interpretation. While the philosopher of love would simply forward vague conceptions of right or wrong, MacIan demands a relationship between discourse and the true being of entities. In light of this, his response to the philosopher's drawn out monologue regarding moral planes and the power of love to breed love is understandable:

"Talk about the principle of love as much as you like. You seem to me colder than a lump of stone; but I am willing to believe that you may at some time have loved a cat... But don't you talk about Christianity... It is a thing that has made men slay and torture each other; and you will never

32 Ibid., p. 78.

33 Ibid., p. 51. 
know why... Hate it, in God's name, as Turnbull does, who is a man. It is a monstrous thing, for which men die." 34

In Being and Time, Heidegger asserts that conscience, wrongly interpreted as power, passes itself off as, "recognizing the call in the sense of a voice which is 'universally" binding." It is upon just such a 'universal,' ideological concept of love and nature that Chesterton's philosopher has grounded his appeal: and it is on this ground that Maclan objects. As Heidegger writes later, "A 'world-conscience' is a dubious fabrication, and Dasein can come to this only because conscience, in its basis and its essence, is in each case mine." ${ }^{35}$ This is precisely the flaw which Maclan points out in the man's argument. Conscience, by being mine, is something that rises from within and recalls me to myself; it has nothing to do with abstract concepts I have never experienced. Unlike MacIan and Turnbull, whose beliefs are authentically theirs, the philosopher of love preaches something about which he has theorized, but has never made his own. As such, his appeal is empty, removed from any truth authenticated by his being.

Although the dialogue and action of Chesterton's characters largely confirm Heidegger's take on the difference between authentic and fallen Dasein, they likewise emphasize a missing element in his conception of resoluteness and death. In analyzing the motives of the novel's characters, Chesterton's stance becomes clear: it is not enough for one to resolutely project possibilities in relation to guilt; one must also stand for something before death - otherwise, Dasein's freedom is simply the freedom to be miserable.

One of the characters encountered along the gentlemen's path is a young, beautiful woman, nameless until the novel's conclusion. After saving the men from the police, the young woman speaks in the following way, evidencing by her words both the power of resoluteness and the necessity for a reason to be so:

"God knows I have had no pleasure in my life, though I am pretty and young and father has plenty of money. And then people come and tell me that I ought to do things and I do them and it's all drivel...I am to save children from death, and I am not even certain that I should not be better off dead... It seems to me ...that there is no way of being happy... but I may be wrong... I felt that, after all, you had got the way out and that was why the world hated you. You see, if there were a way out, it would be sure to be something that looked very queer." 36

The girl's words elicit three facts. Firstly, the uncanniness of anxiety is at work, betraying itself in her unhappiness. Secondly, this anxiety has not induced her to project her own possibilities or to be resolute. This last fact is a curious one, for it

34 Ibid., p. 52.

35 Heidegger, Being and Time, p. 278.

36 Chesterton, The Ball and the Cross, p. 94. 
illustrates a deficiency in Heidegger's description of resoluteness. The girl is plainly aware of the call of conscience. Her manner of speaking about death, moreover, shows that she views it neither with tranquility nor horror, but as the factical impossibility of her possibility. Furthermore, she is acutely aware that the public proposal of the 'they' is not a course of action which appeals to her authentic being and she longs for some possibility in the projection of which she might be resolute. Yet, for all this, she cannot form a resolution: her pessimistic understanding of death fails to free her possibilities, and her guilt as ground for resolution is barren, since she has no reason to choose one course over another. Faced with this anxious responsibility of choice, yet lacking anything to stand for, the burden of her guilt becomes what it is not for the authentically resolute; it becomes a grievous weight. She has nothing to be resolute for in the face of death: would it not be better then, to be dead?

Considering this burden, the woman's encounter with resolution is fascinating. In his section on resoluteness, Heidegger declares that resolute Dasein, in light of its chosen potentiality for being, "frees itself for its world," making it possible both to let Others "be," and to become the "conscience" of Others. ${ }^{37}$ At this point, it should be clear that the Scotsmen are authentically resolute. Their fatal challenge demonstrates that the projection of each man is grounded upon his embrace of his own, personal responsibility for choice among possibilities made free by the facticity of death. The men act in whatever way appears fitting to their authentic being: they evade the law; they dialogue hotly with interlocutors; they challenge each other in a fight to the death. Every possibility is open to them - and in fact, they choose these possibilities - not because they disdain civilization, but because living authentically (with regard to guilt and in light of death) means recognizing that each possibility matters, and that we must act upon those that correspond to our authentic being. For these men, guilt is not grievous, but a personal challenge concerning the urgency of their choice. As Turnbull declares toward the beginning of the book: "We must fight this thing out somewhere; because, as you truly say, we have found each other's reality. We must kill each other - or convert each other." ${ }^{38}$ In the encounter with these men, the woman has met resoluteness, and moreover been called by it. This, then, is the third fact: the resolution ${ }^{39}$ of the Scotsmen has acted as a more effective conscience than her own, for unlike her uncanniness, their duel expresses a proposal: a reason, a thing worth fighting for.

37 Heidegger, Being and Time, p. 344.

38 At one point in his book, Heidegger writes, "along with the sober anxiety which brings us face to face with our individualized potentiality-for-being, there goes an armed joy in this possibility" (310). Although Chesterton never explicitly displays his protagonists dealing with the burden of anxiety, he does make one aspect of their characters manifest: they are not at home. The Ball and the Cross is primarily an account of two men's rebellion against the public and all its tranquil homeliness. Readers see clearly, moreover, that within this very rebellion the men engage themselves, others, and the world around them with a fierce positivity. It is apparent then, that Chesterton understands existentiel authenticity to take a similar form to that which Heidegger ascribes to it.

39 The term 'resolution' is here employed in place of 'resoluteness', because resoluteness is not a rigid position. Before every possibility, Dasein has the capacity of choosing resolutely - of reaffirming its authenticity. Thus two resolutions, though both authentic, may not resemble each other. Our argument, as put forward above, nevertheless remains the same: in order to make an authentic resolution - to choose in awareness of our full responsibility - we must have a reason to do so. 
This theme is referenced again towards the end of the novel. The master of the asylum gathers everyone together and declares that, in the interest of handling such a trivial truth as that of a religious duel (which, nonetheless, had so discomfited the populace), the story of Maclan's challenge had been researched and declared a fable. Accordingly, every person who had testified that they had come across the duo had therefore been diagnosed as pathological and placed in the asylum's care. The master's statement is interpretable as a literary confirmation of the 'they's' control. Though perhaps unrealistic in its abrupt development, the storyline emphasizes the challenge which authentic lives present to public tranquility, and a firm intent to cover them up. However, in the interest of such denial, any authentic mode of Being-with one another must be denied.

Among the individuals locked in the asylum is a man, Durand, whose life has been a demonstration of authenticity. "Simply a man," he has lived with his potentiality-forBeing in mind, and made every existentiel decision in view of his ownmost possibility. He genuinely understands himself as the man of Rousseau's social contract, and therefore projects his possibilities authentically, finding himself in them. Immediately before the master's speech, recognizing that his situation in life has fallen "below the comfort of barbarism," Durand demands that a psychologist admit that the social contract has been annulled. The doctor, considering the matter irrelevant, acknowledges that it has. Durand exits, returning only after he has set the building aflame "in accordance with the strict principles of the social contract." ${ }^{40}$ Before fleeing the scene, the doctors betray a moment's irresolution, crying out, "how do you know we shall go?", but Maclan's response silences them: "You believe nothing... and you are insupportably afraid of death." ${ }^{41}$ His simple statement speaks volumes. While the doctors, failing to understand the nature of death, reduce it to something merely to be feared, Durand, Maclan, Turnbull, and every other individual locked in the asylum see it as that in light of which their own possibilities are given meaning. They can make the decision to stand true to their beliefs because they believe in something worth acting for in view of death: be it Catholicism, its opposite, the social contract, or the simple fact of their challenged truth. The "lunatics" are authentic for a reason.

Over the course of this discussion, I hope that it has become evident not only what Heidegger's particular thoughts are regarding fallenness, anxiety, conscience, guilt and resolution, but also that Chesterton largely affirms his position regarding these matters(and the forms they adopt in an existentiel sense). However, it should likewise be obvious that, by emphasizing a connection between one's reason for choosing a possibility, and the fact of one's authentically doing so, Chesterton has revealed a gap in Heidegger's philosophy. According to the latter, one must merely be called by uncanniness to an openness before death, for one to project possibilities authentically and responsibly. Yet, Chesterton maintains that this is not enough. For, even if

40 Ibid., p. 197

41 Ibid., p. 197 
Dasein allows its listening to be directed away from the "they" by anxiety, it will fail to embrace its guilt: it will not choose without a reason to do so - without a belief worth dying for.

\section{BIBLIOGRAPHY}

Chesterton, G.K. The Ball and the Cross. Sioux Falls: NuVision Publications, LLC, 2008.

Dahlstrom, Daniel O. The Heidegger Dictionary. New York: Bloomsbury Publishing Plc, 2013.

Heidegger, Martin. Being and Time. New York: Harper \& Row, 1962. 